\title{
PERAN PENDIDIKAN DAN PENDAPATAN TERHADAP KEHAMILAN REMAJA
}

\author{
Friska Realita ${ }^{1}$, Arum Meiranny ${ }^{2}$ \\ ${ }^{1,2}$ Program Studi DIII Kebidanan, Universitas Islam Sultan Agung
}

Email: friskarealita@unissula.ac.id

\begin{abstract}
ABSTRAK
Semakin muda usia seorang ibu ketika hamil, semakin besar risiko terhadap kesehatannya. Sebuah penelitian yang dilakukan di Amerika Latin menunjukkan bahwa perempuan yang melahirkan sebelum usia 16 tahun, tiga hingga empat kali lebih mungkin menderita kematian dari wanita yang melahirkan pada usia 20 tahun. Komplikasi yang berhubungan dengan kehamilan seperti gugur kandungan atau aborsi, pre eklampsia, eklampsia, dan berat bayi lahir rendah merupakan penyebab terjadinya kematian ibu hamilPenelitian ini merupakan penelitian analitik observasional dengan rancangan cross sectional. Uji statistik yang digunakan dalam penelitian ini adalah uji Chi Square dan untuk menghitung besarnya risiko, menggunakan perhitungan RR dengan CI 95\%. Penelitian dilakukan di Rumah Sakit Islam Sultan Agung Semarang pada Bulan Maret-April 2017. bahwa terdapat pengaruh pendidikan terhadap kehamilan remaja dan tidak terdapat pengaruh pendapatan terhadap kehamilan remaja Saran bagi bidan adalah bisa diharapkan dapat memberikan konseling tentang perilaku remaja dimulai dari nilai keluarga, komunikasi anak dan orang tua, dan komunikasi guru dan murid serta lingkungan masyarakat. Orang tua diharapkan dapat lebih meningkatkan komunikasi dengan anak, sehingga anak lebih terbuka untuk berbagi cerita dengan orang tua. Diharapkan peneliti selanjutnya dapat lebih menggali faktor-faktor lain yang berhubungan dengan kehamilan remaja, yang belum diteliti.
\end{abstract}

\section{Kata kunci: pendapatan; pendidikan; kehamilan remaja}

\section{THE ROLE OF EDUCATION AND REVENUE ON TEENS PREGNANCY}

\begin{abstract}
Adolescence is a period of rapid growth and development of physical, psychological, intellectual, and sexual. One of the phenomenon of adolescent life is very prominent is the occurrence of his increased of sexuality, then the phenomenon of adolescent pregnancy. The aim of this study was to analyze the factors that affect the occurrence of pregnancy in adolescents at the Islamic Hospital of Sultan Agung Semarang. This study was an observational analytic study with cross-sectional design. The statistical test used in this study was the frequency distribution to assess the characteristics, to test the variables in the two study groups using Chi Square or Eksak Fisher test, and to calculate the risk factor used Relative Risk with 95\% confidence interval. The study was held at Sultan Agung Semarang Islamic Hospital in March-April 2017. The result of this research are there are an influence of education on adolescent pregnancy $(p<0,05)$ and there was no influence of income to adolescent pregnancy $(p>0,05)$. Suggestion for midwife is expected to provide counseling about adolescent behavior starting from family value, communication of child and parents, and communication of teacher and student and society environment. Parents are expected to further improve communication with children, so children are more open to share stories with parents. It is expected that further researchers can further explore the factors that are associated with teen pregnancy.
\end{abstract}

Keywords: education; incom; adolescent pregnancy 


\section{Pendahuluan}

Semakin muda usia seorang ibu ketika hamil, semakin besar risiko terhadap kesehatannya. Sebuah penelitian yang dilakukan di Amerika Latin menunjukkan bahwa perempuan yang melahirkan sebelum usia 16 tahun, tiga hingga empat kali lebih mungkin menderita kematian dari wanita yang melahirkan pada usia 20 tahun. Komplikasi yang berhubungan dengan kehamilan seperti gugur kandungan atau aborsi, pre eklampsia, eklampsia, dan berat bayi lahir rendah merupakan penyebab terjadinya kematian ibu hamil (BKKBN, 2012).

Pada tahun 2014 World Health Statistics menunjukkan bahwa angka kejadian kehamilan remaja di dunia di kalangan wanita yang berusia 15 sampai 19 tahun adalah 49 per 1.000 perempuan. Angka kejadian kehamilan remaja di Indonesia adalah 48 per 1.000 perempuan. Angka kejadian kehamilan remaja di Indonesia tergolong tinggi dibandingkan 6 di Malaysia dan 41 di Thailand (World Bank Group).

Menurut laporan Riskesdas 2013, dikemukakan bahwa 2,6 persen perempuan di antara usia 10-54 tahun menikah pertama kali pada umur kurang dari 15 tahun dan 23,9 persen perempuan menikah pada umur 15-19 tahun. Salah satu masalah kesehatan reproduksi adalah menikah pada usia dini. Hal ini karena jangka masa seorang perempuan untuk bereproduksi lebih panjang jika menikah pada usia muda. Angka kehamilan penduduk perempuan 10-54 tahun adalah 2,68\%. Terdapat kehamilan pada umur kurang dari 15 tahun sebanyak 0,02\% dan kehamilan pada umur 15-19 tahun sebesar 1,97 persen (Riskesdas, 2013).

Banyak faktor yang dapat mempengaruhi remaja untuk menikah di usia muda, yang selanjutnya akan hamil dan melahirkan diusia muda antara lain adalah pendidikan dan pendapatan (ekonomi ). makin rendah tingkat pendidikan, makin mendorong cepatnya perkawinan muda. Dari segi Ekonomi apabila anak remaja nya menikah berarti sudah bebas dari tanggung jawab dan bisa mengurangi beban di keluarganya.

Pendidikan seks yang kurang di kebanyakan negara menyebabkan beberapa gadis tidak tahu cara menghindari hamil. Mereka mungkin merasa terlalu malu untuk mencari layanan kontrasepsi, kontrasepsi mungkin terlalu mahal atau tidak banyak atau secara hukum tidak tersedia. Bahkan ketika kontrasepsi yang banyak tersedia, remaja perempuan yang aktif secara seksual cenderung menggunakannya daripada orang dewasa (WHO, 2013).

Rumah Sakit Islam Sultan Agung adalah salah satu rumah sakit yang berada di wilayah perbatasan antara perkotaan dan pedesaan, sehingga terdapat beberapa ibu hamil yang masih berusia remaja dari wilayah pedesaan yang datang untuk melakukan periksa hamil. 
Berdasarkan studi pendahuluan yang penulis lakukan pada Bulan Januari 2017, terdapat 10 ibu hamil yang masih berusia dewasa.

Dari uraian tersebut, penulis tertarik untuk melakukan penelitian tentang faktor-faktor yang mempengaruhi terjadinya kehamilan pada remaja di Rumah Sakit Islam Sultan Agung Semarang

\section{Tinjauan Teoritis}

Remaja adalah masa transisi dari alam anak ke alam dewasa yang berlaku pada umur 1119/20 tahun. Pada masa ini seseorang akan mulai menjadi matang dengan menunjukkan ciriciri seks sekunder. Sehingga mulai muncul adanya ketertarikan kepada lawan jenis.

Kehamilan usia dini (usia muda/remaja) adalah kehamilan yang terjadi pada remaja putri berusia <20 tahun. Kehamilan tersebut dapat disebabkan oleh karena hubungan seksual (hubungan intim) dengan pacar, dengan suami, pemerkosaan, maupun faktor-faktor lain yang menyebabkan sperma membuahi telurnya dalam rahim perempuan tersebut. Banyak faktor yang dapat mempengaruhi remaja untuk menikah di usia muda, yang selanjutnya akan hamil dan melahirkan di usia muda antara lain : Tingkat pendidikan, ekonomi, pengetahuan tentang kesehatan reproduksi, hukum atau peraturan, adat istiadat atau pandangan masyarakat, dorongan biologis, kepatuhan terhadap orang tua, adanya kesempatan melakukan hubungan seks pra nikah, pandangan terhadap konsep cinta. Selain itu, faktor-faktor yang berkontribusi terhadap kehamilan remaja yaitu: tradisi yang mengarah pada pernikahan dini (negara berkembang), perilaku seksual remaja yang juga dapat dipengaruhi oleh alkohol dan obatobatan, kurangnya pendidikan dan informasi mengenai kesehatan seksual reproduksi. terutama dari orang tua, tekanan teman sebaya untuk terlibat dalam aktivitas seksual, kurangnya akses ke alat-alat yang mencegah kehamilan sehingga dapat menyebabkan penggunaan kontrasepsi yang tidak tepat, pelecehan seksual, kemiskinan, kekerasan dan pelecehan yang terjadi dalam rumah tangga, harga diri rendah, faktor sosio demografik, (kemiskinan, kebiasaan, peran wanita di masyarakat, seksualitas aktif, media massa, hubungan antar keluarga yang tidak harmonis), Status perkembangan (kurang pemikiran tentang masa depan, ingin mencoba-coba, Kebutuhan terhadap perhatian, penggunaan dan penyalahgunaan obat-obatan). 


\section{Metode Penelitian}

Penelitian ini adalah jenis penelitian analitik observasional dengan rancangan crossectional untuk mendeskripsikan faktor-faktor yang mempengaruhi kehamilan pada remaja. Subjek penelitian ini adalah seluruh remaja di RSI Sultan Agung yang memenuhi penelitian dan bersedia menandatangani lembar persetujuan setelah diberikan penjelasan. Instrumen pengumpulan data menggunakan kuesioner yang berupa checklist. Analisa statistik yang digunakan dalam penelitian ini adalah uji Chi Square. Untuk menghitung besarnya risiko, dengan menggunakan perhitungan Risiko Relatif dengan confidence interval 95\%. Tempat Penelitian dilakukan di Rumah Sakit Islam Sultan Agung Semarang. Waktu penelitian Penelitian ini dilaksanakan pada Bulan Maret-April 2017.

\section{Hasil Penelitian}

Hubungan Pendidikan dan Kehamilan Remaja

Tabel 1 Hubungan Pendidikan dan Kehamilan Remaja

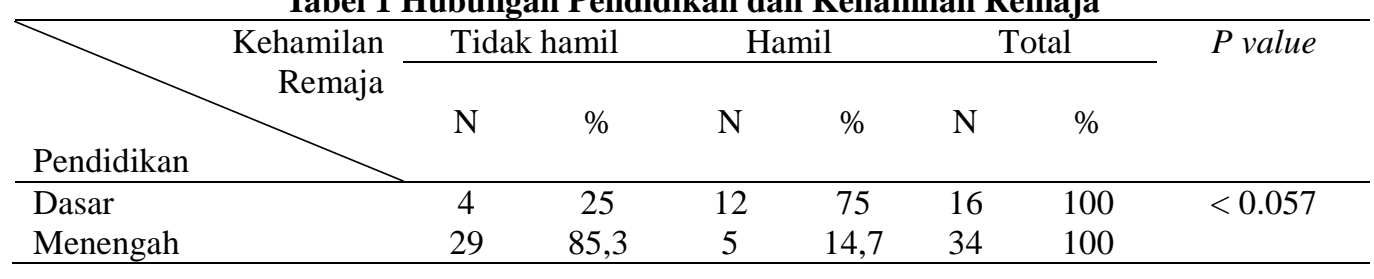

Berdasarkan tabel 1 dapat diketahui bahwa dari sejumlah responden yang pendidikan terakhirnya di tingkat dasar, sebagian besar mengalami kehamilan, yaitu sebesar $75 \%$, dan yang tidak mengalami kehamilan sebesar $25 \%$. Sedangkan responden yang pendidikan terakhirnya di tingkat menengah, sebagian besar tidak mengalami kehamilan, yaitu sebesar $85,3 \%$, dan yang mengalami kehamilan sebesar $14,7 \%$. $P$ value diperoleh $<0,05$, dengan OR 0,057 .

Hubungan Pendapatan dan Kehamilan Remaja

Tabel 2 Hubungan Pendapatan dan Kehamilan Remaja

\begin{tabular}{lcccccccc}
\hline & Kehamilan Remaja & \multicolumn{2}{c}{ Tidak hamil } & \multicolumn{2}{c}{ Hamil } & \multicolumn{2}{c}{ Total } & \multirow{2}{*}{ P value } \\
\cline { 2 - 7 } Pendapatan & $\mathrm{N}$ & $\%$ & $\mathrm{n}$ & $\%$ & $\mathrm{~N}$ & $\%$ & \\
\hline <UMR & 20 & 17,2 & 6 & 8,8 & 26 & 100 & 0.09 \\
>UMR & 13 & 54,2 & 11 & 45,8 & 24 & 100 & \\
\hline
\end{tabular}

Berdasarkan tabel 2 dapat diketahui bahwa dari sejumlah responden yang pendapatannya <UMR, sebagian besar tidak mengalami kehamilan, yaitu sebesar 17,2\%, dan yang mengalami kehamilan sebesar $8,8 \%$. Sedangkan responden yang pendapatannya $\geq$ UMR, 
sebagian besar tidak mengalami kehamilan, yaitu sebesar 54,2\%, dan yang mengalami kehamilan sebesar 45,8\%. P value diperoleh 0,09 dengan OR 2,821.

Berdasarkan tabel 2 dapat diketahui bahwa dari sejumlah responden yang pendapatannya <UMR, sebagian besar tidak mengalami kehamilan, yaitu sebesar 17,2\%, dan yang mengalami kehamilan sebesar 8,8\%. Sedangkan responden yang pendapatannya $\geq \mathrm{UMR}$, sebagian besar tidak mengalami kehamilan, yaitu sebesar 54,2\%, dan yang mengalami kehamilan sebesar 45,8\%. $P$ value diperoleh 0,09 dengan OR 2,821. Sehingga dapat diketahui bahwa tidak terdapat pengaruh yang signifikan antara pendapatan dengan kejadian kehamilan remaja.

Masalah kemiskinan merupakan salah satu faktor yang menyebabkan kehamilan usia dini. Pada beberapa wilayah, ketika kemiskinan benar-benar menjadi permasalahan yang sangat mendesak, perempuan muda sering dikatakan sebagai beban ekonomi keluarga. Oleh karenanya perkawinan usiadini dianggap sebagai suatu solusi untuk mendapatkan mas kawin dari pihak laki-laki untuk menganti seluruh biaya hidup yang telah dikeluarkan oleh orangtuanya.

Secara sosial ekonomi, pernikahan remaja menjadi salah satu gejala yang menunjukkan rendahnya status wanita. Pada beberapa kasus, pernikahan remaja berkaitan dengan terputusnya kelanjutan sekolah wanita yang berakibat pada tingkat pendidikan wanita menjadi rendah. Pendidikan yang rendah akan merugikan posisi ekonomi wanita dan rendahnya tingkat partisipasi kerja wanita. Penelitian ini tidak sesuai dengan penelitian yang dilakukan oleh Chariroh (2004) di Kabupaten Pasuruan, yang menyatakan bahwa salah satu faktor yang menyebabkan kehamilan di usia muda adalah pendapatan.

\section{Pembahasan}

\section{Hubungan Pendidikan dan Kehamilan Remaja}

Berdasarkan hasil penelitian diketahui bahwa pendidikan memiliki pengaruh terhadap kehamilan remaja, dengan OR 0,057. Hal tersebut menunjukkan bahwa remaja yang memiliki pendidikan rendah, memiliki resiko sebesar 0,057 kali untuk mengalami kehamilan.

Pendidikan rendah yang dimaksud dalam penelitian ini adalah orang yang pendidikan terahirnya SD dan SMP, sedangkan untuk pendidikan tinggi adalah SMA dan perguruan tinggi.

Menurut BKKBN (2011) umumnya mereka yang melakukan pernikahan dini adalah mereka yang memiliki pendidikan SD, SLTP dan SLTA.Semakin rendah tingkat 
pendidikan, semakin mendorong pernikahan dini (Roumli \& Anna, 2009). Rendahnya tingkat pendidikan dan pengetahuan mempengaruhi pola fikir terbatas yang akan berdampak pada perilaku individu (Romauli \& Anna, 2012).

Tingkat pendidikan merupakan salah satu faktor internal yang mempengaruhi pernikahan dini. Tingkat pendidikan seseorang mempengaruhi cara pandang dan berfikir seseorang maka akan semakin banyak pengetahuan yang didapatkan, sehingga dengan pengetahuan yang lebih banyak diharapkan dalam pengambilan keputusan untuk melakukan pernikahan akan semakin logis. Tingkat pendidikan yang rendah dapat mempengaruhi kehidupan seorang wanita termasuk dengan kehidupan berumah tangga.Pengetahuan yang rendah menyebabkan seseorang kurang memiliki pengetahuan dan kesiapan dalam menghadapi pernikahan, sehingga dalam pengambilan keputusan untuk menikah tidak banyak memiliki pertimbangan.

Tingkat pendidikan adalah salah satu faktor yang mempengaruhi terjadinya pernikahan dini (Roumli \& Anna, 2009). Semakin rendah pendidikan seseorang akan cenderung melakukan pernikahan dini karena tingkat pendidikan dan pengetahuan yang rendah dapat mempengaruhi pola pikir terbatas yang berdampak pada perilaku seseorang, termasuk dalam pengambilan keputusan untuk menikah.

Hasil penelitian ini sejalan dengan penelitian Stang (2011) yang menyatakan bahwa terdapat hubungan pendidikan dengan pernikahan dini.Penelitian yang dilakukan oleh Yunita (2015) juga menyatakan bahwa remaja dengan pendidikan dasar memiliki peluang atau resiko melakukan pernikahan dini 9,750 kali lebih besar dibandingkan dengan remaja yang memiliki pendidikan menengah.Berdasarkan hasil penelitian ini dapat diasumsikan rendahnya rendahnya pendidikan membuat kurangnya pengetahuan yang didapatkan. Wanita yang memiliki pengetahuan yang kurang akan membuat keputusan untuk melakukan pernikahan dini tanpa mempertimbangkan dampak yang ditimbulkan dari pernikahan dini itu sendiri.

Sejalan dengan penelitian sebelumnya yang dilakukan oleh Stang (2011), mengatakan bahwa orang yang berpendidikan rendah cenderung melakukan pernikahan dini disebabkan rendahnya pengetahuan mereka terkait pernikahan dini. Menurut Kumalasari dan Iwan (2012), dampak dari pernikahan dini adalah alat reproduksi belum siap menerima kehamilan sehingga dapat menimbulkan beberapa komplikasi, banyaknya kasus menikah dini berbanding lurus dengantingginya angka perceraian, dan psikologi yang belum matang, sehingga cenderung labil dan emosi, dibuktikan di 
Kecamatan Gamping kasus perceraian yang disebabkan oleh perselisihan terus menerus menjadi peringkat dua yaitu terdapat 7 kasus $(33,3 \%)$.

Romauli dan Anna (2012) mengatakan tingkat pendidikan dan pengetahuan yang rendah mempengaruhi pola pikir terbatas yang akan berdampak pada perilaku individu. Pendidikan dapat mempengaruhi penentuan sikap seseorang dalam mengambil keputusan, termasuk keputusan untuk menikah. Ketika seseorang mempunyai pendidikan yang semakin tinggi diharapkan akan mendapatkan informasi yang semakin banyak, dari informasi tersebut dapat meningkatkan pengetahuan seseorang sehingga dengan pengetahuan seseorang dapat menentukan sikap yang bijak dalam pengambilan keputusan untuk menikah.

Pernyataan ini sejalan dengan Kumalasari dan Iwan (2012) yang menyatakan bahwa tingkat pendidikan seseorang mempengaruhi pernikahan dini.Remaja yang memiliki latar belakang pendidikan tinggi memiliki risiko lebih kecil untuk melakukan pernikahan dini dibandingkan dengan mereka yang memiliki pendidikan rendah.Hal ini dikarenakan pengetahuan meraka dapatkan lebih banyak. Menurut Desiyanti (2015) pendidikan seseorang merupakan bagian yang sangat penting dari masalah yang ada dalam diri seseorang, karena dengan pendidikan seseorangakan mendapatkan pengetahuan yang nantinya akan membentuk sikapnya dalam membuat keputusan.

Terdapat hubungan antara tingkat pendidikan istri dengan pernikahan dini di Kecamatan Gamping, tingkat pendidikkan akan mempengaruhi pola pikir dan pengambilan keputusan untuk menikah, mayoritas remaja di Kecamatan Gamping hanya dapat menyelesaikan pendidikan hingga SMA/SLTA karena keterbatasan ekonomi mereka tidak dapat melanjutkan sekolah hingga perguruan tinggi selain itu juga karena tidak memiliki aktivitas setelah lulus sekolah sehingga para remaja memutuskan menikah tanpa mempertimbangkan usianya.

Pendidikan dalam arti formal adalah suatu proses penyampaian bahan atau materi pendidikan oleh pendidik kepada sasaran pendidikan (anak didik) guna mencapai perubahan tingkah laku. Pendidikan merupakan salah satu sarana untuk meningkatkan kecerdasan dan keterampilan manusia sehingga kualitas sumber daya manusia tergantung dari kualitas pendidikan. Pendidikan berhubungan dengan kemampuan baca tulis dan kesempatan seseorang menerima serta menyerap informasi sebanyakbanyaknya.

Hal senada juga dikemukakan Rahman and Kabir (2005) factor yang menyebabkan perkawinan dan kehamilanusia dini di Bangladesh adalah pendidikan. Menurut Hanum 
(1997), yang melakukan penelitian di Bengkulu Utara salah satu faktor yang berkaitan tinggi rendahnya usia kawin pertama adalah rendahnya akses kepada pendidikan. Rendahnya tingkat pendidikan disebabkan oleh ekonomi keluarga yang kurang. Kekurangan biaya menjadi kendala bagi kelanjutan pendidikan. Choe et al. (2004) mengemukakan tingkat pendidikan seseorang berhubungan dengan pernikahan dan kehamilan usia dini.

Tingkat pendidikan yang lebih tinggi berhubungan dengan menurunnya kemungkinan menikah di usia dini. Laki-laki dan perempuan di Nepal tidak menikah selama masa pendidikan. Demikian juga penelitian yang dilakukan Chariroh (2004) di Kabupaten Pasuruan didapatkankan bahwa salah satu faktor yang menyebabkan perkawinan dan kehamilan di usia muda adalah pendidikan.

2. Hubungan Pendapatan dan Kehamilan Remaja

Berdasarkan Hasil penelitian diketahui bahwa tidak terdapat pengaruh yang signifikan antara pendapatan dengan kejadian kehamilan remaja. Masalah kemiskinan merupakan salah satu faktor yang menyebabkan kehamilan usia dini. Pada beberapa wilayah, ketika kemiskinan benar-benar menjadi permasalahan yang sangat mendesak, perempuan muda sering dikatakan sebagai beban ekonomi keluarga. Oleh karenanya perkawinan usiadini dianggap sebagai suatu solusi untuk mendapatkan mas kawin dari pihak laki-laki untuk menganti seluruh biaya hidup yang telah dikeluarkan oleh orangtuanya.

Secara sosial ekonomi, pernikahan remaja menjadi salah satu gejala yang menunjukkan rendahnya status wanita. Pada beberapa kasus, pernikahan remaja berkaitan dengan terputusnya kelanjutan sekolah wanita yang berakibat pada tingkat pendidikan wanita menjadi rendah. Pendidikan yang rendah akan merugikan posisi ekonomi wanita dan rendahnya tingkat partisipasi kerja wanita. Penelitian ini tidak sesuai dengan penelitian yang dilakukan oleh Chariroh (2004) di Kabupaten Pasuruan, yang menyatakan bahwa salah satu faktor yang menyebabkan kehamilan di usia muda adalah pendapatan.

\section{Kesimpulan}

Ada pengaruh pendidikan dan pendapatan terhadap kehamilan remaja. 


\section{Saran}

Diharapkan dapat memberikan konseling tentang perilaku remaja dimulai dari nilai keluarga, komunikasi anak dan ortu, dan komunikasi guru dan murid serta lingkungan masyarakat. Orang tua diharapkan dapat lebih meningkatkan komunikasi dengan anak, sehingga anak lebih terbuka untuk berbagi cerita dengan orang tua. Diharapkan peneliti selanjutnya dapat lebih menggali faktor-faktor apa saja yang berhubungan dengan kehamilan remaja.

\section{Daftar Pustaka}

Banepaa, Amanda, Maria Lupita N. Meo., Angela M. Gatum. Gambaran faktor-faktor yang mempengaruhi Kehamilan remaja usia 14-19 tahun di Kelurahan Bakunase wilayah kerja Puskesmas Bakunase Kota Kupang. CHMK Nursing Scientific Journal. 1(2) Oktober 2017.

BKKBN. 2011. Kajian Profil Penduduk Remaja (10-24 tahun): Ada apa dengan remaja?. Diakses tanggal 25 Januari 2017,(www.bkkbn.go.id).

. 2012. Resiko Kehamilan Usia Muda. Diakses tanggal 25 Januari 2017 M (http://banten.bkkbn.go.id/Lists/Artikel/DispForm.aspx?ID=270\&ContentTypeId=0x0 1003DCABABC04B7084595DA364423DE7897).

Depkes, Poltekkes. 2010. Kesehatan Remaja Problem dan Solusinya. Jakarta : Salemba Medika.

IDAI. 2013. Kesehatan Reproduksi Remaja dalam Aspek Sosial. Diakses tanggal 24 Januari 2017, (http://idai.or.id/public-articles/seputarkesehatan-anak/kesehatan-reproduksiremaja-dalam-aspek-sosial.html)

Kamus Besar Bahasa Indonesia. 2008. Pusat Bahasa Departemen Pendidikan Nasional. Jakarta.

Kumalasari, Intan, dkk. 2012. Kesehatan Reproduksi untuk Mahasiswa Kebidanan dan Keperawatan. Jakarta: Salemba Medika.

Manuaba, IBG. Dkk. 2010. Ilmu Kebidanan, Penyakit Kandungan, dan KB Untuk Pendidikan Bidan. Edisi 2. Jakarta : EGC.

Marcell, A.V., Wibbelsman, C., Seigel, W.M. 2011. Male Adolescent Sexual and Reproductive Health Care. Pediatrics; 128: 1658-1678.

Marmi. 2013. Kesehatan Reproduksi. Yogyakarta : Pustaka Pelajar

Rosa, D. 2012. Analisis Faktor Memengaruhi Kehamilan Usia Muda di Kecamatan Binjai Kabupaten Langkat. Fakultas Kesehatan Masyarakat. Universitas Sumatera Utara, Medan. 
Sarwono, Sarlito Wirawan. 1981. Pergeseran Norma Perilaku Seksual Kaum Remaja : Sebuah Penelitian terhadap Remaja Jakarta. Jakarta : Rajawali.

Soetjiningsih. 2004. Tumbuh Kembang Remaja dan Permasalahannya. Jakarta: EGC.

Undang-Undang Pernikahan Republik Indonesia No.I tahun 1974. Tentang Perkawinan Surabaya. Penerbit Pustaka Tinta Mas.

United Nations Children's Fund. 2011. Adolescent An Age Of Opportunity. New York. Diakses tanggal 24 Januari 2017 (http://data.unicef.org/corecode/uploads/document6/ uploaded_pdfs/corecode/SOWC_2011_83.pdf)

WHO. 2003. Adolescent Friendly Health Service, An Agenda For Change.

Setyowati Heni Eti Rahayu1, Septiyati Purwandari ,Kartika Wijayanti. Faktor Determinan dan Resiko Kehamilan Remaja Di Kecamatan Magelang Selatan Tahun 2017. URECOL. The 6th University Research Colloquium 2017 Universitas Muhammadiyah Magelang.

Syafangah, Umi. Hubungan Tingkat Pendidikan Dan Pekerjaan Dengan Pernikahan Dini pada Remaja Putri di Kecamatan Gamping Kabupaten Sleman Tahun 2016. Naskah publikasi Unpublished. 